\title{
The Effect of Moral Intensity, Ethical Decision Making, Professional Commitment, and Anticipatory Socialization on Whistleblowing Intention
}

\author{
Dina Nurdianawati*, Riani Rachmawati \\ Magister of Management \\ Universitas Indonesia \\ Jakarta, Indonesia \\ *dina.nurdianawati@gmail.com
}

\begin{abstract}
The focus of this study is to examine the relationship between individual perceptions related to moral intensity over an ethical situation mediated by ethical decision making towards whistleblowing intention and to examine the relationship between professional commitment and anticipatory socialization towards whistleblowing intention. This research uses a quantitative approach using a survey method by distributing questionnaires to respondents. Information was collected from 268 respondents obtained from 6 (six) government offices, which serve foreign taxpayers, and analysed using Structural Equation Modelling-Partial Least Square (SEM-PLS). The results show that moral intensity related to ethical situations is positively related to ethical decision making, namely recognition of ethical problems, consideration of perceptions, ethical judgment, and ethical intention. Moral intensity directly has a positive effect on whistleblowing intention, but if through mediating ethical decision making, the results show no positive effect on whistleblowing intention. Meanwhile, the factors of professional commitment and anticipatory socialization produce a positive influence on whistleblowing intention. We suggest the next researcher to explore other mediator variables, examine external factors of whistleblowing intentions, design more specific research of whistleblowing and expand the sample. This result provides input to Government Institution in supporting whistleblowing policies and systems effectively, by understanding which factors have more influences on employees' commitment to take whistleblowing action.
\end{abstract}

Keywords: moral intensity, ethical decision making, professional commitment, anticipatory socialization, whistleblowing intention

\section{INTRODUCTION}

Ethical, by definition in general, is closely related to the principle of morality, right and wrong in doing something. Fraudulent or unethical acts are often carried out by employees in the workplace, including in government institution. The potential for unethical acts to occur in the government sectors can happen when procurement of goods and services, holding meetings or conventions, forming teams, planning a business trips and others.
The unethical act is not clearly visible as the act of fraud that was already regulated by the law. It is said to be unethical because it violates the principle of morality, such as taking action or making decisions without considering the urgency, priority, functional aspects, and especially negating the cost efficiency side. They were conducted in order to accelerate the absorption of the budget, the achievement of performance indicators regarding the activities implementation or indeed because it is purely for personal self-interest. So for an unethical act, it needs personal analysing from employee's perception using sensitivity of morality.

The Minister of Finance had issued instruction number IMK-346 /IMK.01/2017 regarding The Efficiency Movement as a strengthening of the Ministry of Finance culture, one of which is to carry out budget efficiency. Some individual employees still do not heed this appeal, for example by using airlines that provide flyer point facilities with more expensive costs for business travel, they feel that no legal regulations are violated because official travel costs are used, do not violate the maximum expenditure limit that can be covered, but from moral side, it is wrong and certainly violate the instructions of the Minister of Finance.

An unethical act can lead to be a fraud, if it became a habit and done continuously, followed by more employees, meanwhile other employees neglecting because they considered it as a normal and usual thing to do. This can be detrimental to the state even greater, hurting people's trust and damaging the image of these institutions. To prevent and overcome various acts of unethical behaviour that can harm the government institution both material and immaterial, it need supporting from all employees. Government should encourage their employee to have high sense of moral so that they are motivated to report immediately through whistleblowing, if there any unethical behaviour occurred in the workplace. According to Sweeney \& Costello, whistleblowing is the most effective tool to fight corruption, fraud and other unethical acts compared to the functions of internal control, internal audit or external audit [1].

Basically, whistleblowing is a control mechanism to ensure the check \& balance of a company. Whistleblowing is 
model previously conducted by Valentine and Godkin [9] and professional commitment and also anticipatory socialization factors that have been previously studied by Mela et al [10]. An employee who aware of an ethical issue will be faced with an ethical dilemma, whether he will continue to hide and behave as if he did not know or he will disclose it to the organization where he works. This is where the moral intensity of individual employees play a role, a rational approach that is driven by employee sensitivity to an ethical problem before making an ethical decisions, he will consider whether the decision has been fair and in accordance with applicable law and morals [9].

An employee who feels proud of his profession and his institution can be one of the factors that encourage the disclosure of disciplinary violations and codes of ethics, this is in line with Elias [11] that pride and love for profession, including responsibilities, results obtained, goals and values of a profession, people who are committed to their profession tend to take action whistleblowing (professional commitment). Besides anticipatory socialization factors according to research by Mela et al [10] influence in whistleblowing intention, this is in line with Elias [11] that anticipatory socialization is a process of self-adjustment and belief of certain groups before entering a new environment, including in work environment since they are still in education. Anticipatory socialization has an important role in shaping one's thinking about ethical orientation before entering into his organization.

Several studies on professional commitment and anticipatory socialization factors are mostly conducted with audit student objects, such as those conducted by Elias [11] and Mela et al [10]. In this study, the authors are interested in examining the influence of professional factors commitment and anticipatory socialization, for employees who have worked long hours in government institution, due to the quite high number of fraud in government institutions.

It is hoped that all employees can play an active role as a whistle-blower and support the implementation of the whistleblowing system to run more effectively so that it is expected to prevent and reduce the level of discipline and code of ethics. Because, cases of corruption or other ethical violations committed by individual employees can damage the public image of the institution, especially the Indonesian tax system applies a self-assessment system, where the success of tax collection is inseparable from the trust and awareness of taxpayers in paying taxes closely related to the perception of the institution tax. Positive perceptions of tax institutions can influence the awareness of paying taxes [12].

\section{LITERATURE REVIEW}

\section{A. Whistleblowing Intention}

Whistleblowing is a reporting action carried out by one or more members of an unethical and/or illegal behaviour that occurs in an organization/company [11]. Meanwhile, according to Bjorkelo, whistleblowing is a proactive behaviour in which employees act based on a sense of morality or fairness, and take steps to end mistakes, often this government institution to become a whistle-blower, especially from individual perception factors towards moral intensity and ethical decision making by adopting a research
No matter how sophisticated a whistleblowing system applied by an institution, it will not succeed without the participation and support of all employees, therefore in this a form of "moral protest" by expressing complaints to
companies or institutions, related to an error or other individual is more aware and better understands ethical issues behaviour and/or associated nega by a commitment to respond according to the truth, change ethical issues, as support the research [8]. Consequently, whistleblowing intentions with a fundamental evaluation that results in ethical decisions. 
apart from fear of reprisal in situations where several other members of the organization act [13]. Whistleblowing is a rational process with steps such as identifying the situation in question, deciding whether to report or not disclosing irregularities, responding to reports and becoming a whistleblower [14].

Moral whistleblowing is raised by individuals because of a sense of moral obligation, with ethical sensitivity and moral courage that tends to perceive and report errors. Moral intensity is considered when investigating ethical decision making and complaints because it impacts an individual's evaluation of the circumstances [3] surrounding ethical issues by Valentine and Godkin [9]. Reporting can be directed to internal or external parties, with the aim of influencing ethical and/or illegal violation practices by preventing, detecting, and taking action that can have a deterrent effect.

\section{B. Moral Intensity and Whistleblowing Intention}

Moral intensity is a construct that describes the level of major moral issues in a situation [4]. Another opinion states that moral intensity is a level of strength or weakness of a person's feelings, whether difficult or happy, as a result of an assessment of a good or bad deed, wrong or right, and fair or unjust, this is expressed by Putra and Hariyani [15]. Moral intensity encourages an employee to act based on their evaluation of the situation in question, thereby directing them to whistleblowing for violations that occur. Moral intensity influences reasoning because moral issues have unique and prominent issue contingencies that encourage the assessment of ethical dilemmas, 6 (six) main factors according to Jones [4] consist of magnitude of consequences or (seriousness consequences), social consensus, and probability of effect, temporal immediacy, proximity and concentration of effects.

According to Setyawati [16], an individual with a high level of moral intensity will have a tendency to act fairly and do the right thing. Therefore, an employee who has a high level of moral intensity, tends to report unethical actions or fraud with the consideration that the unethical action is not true and must be reported for the goodness of many people and institutions.

- H1: Moral Intensity has a positive effect on Whistleblowing Intention.

\section{Ethical Decision Making and Whistleblowing Intention}

Definition of ethical decision making (EDM) according to Jones is an ethical / ethical decision making that is widely accepted by the community both legally and morally, otherwise the decision is not ethical, does not meet these criteria [4]. Ethical decision making occurs when an individual negotiates an ethical/ethical dilemma experienced in the workplace, this process is influenced by various paradigms or ethical standards referred to the situation being evaluated.

Robin et al. stated it is normal for an individual to judge a dilemma based on desirable parameters such as fairness when making ethical decisions [8]. According to Rest, to behave morally, an individual performs 4 (four) psychological processes when dealing with an ethical problem, which consists of identifying an ethical problem (recognizing moral issue); conduct an assessment of these ethical issues (moral judgment); establish moral intent/ethics to act or not act (establish moral intent) and engage in ethical/moral behaviour (engage moral behaviour) [7].

- H2: Ethical Decision Making has a positive effect on Whistleblowing Intention.

\section{Moral Intensity and Ethical Decision Making}

According to Jones, moral intensity influences reasoning in ethical decision making because moral problems have unique and prominent problems that drive the assessment of ethical dilemmas [4]. In general, individuals assess an ethical dilemma based on desirable parameters such as fairness or equality when making ethical decisions [8]. An ethical decision is made based on law and morals that are widely supported, while an unethical decision does not meet these criteria [4].

Ethical decision making generally involves a series of sequential steps that occur when ethical issues are considered [17]. Ethical decision making occurs when an employee negotiates ethical dilemmas experienced at work, a process that is influenced by various paradigms/ethical standards that are referred to as situations encountered/evaluated.

- H3: Moral Intensity has a positive effect on Ethical Decision Making.

\section{E. Professional Commitment and Whistleblowing Intention}

An employee with high professional commitment, he will be trusted when carrying out his profession and without being asked to act professionally in accordance with the professional code of ethics. The definition related to professional commitment is expressed by Elias [11], which is a commitment of someone who is formed through his profession. Meanwhile, Mela et al [10] stated that professional commitment is a form of dedication to the profession, professional career and acceptance of professional code of ethics and organizational goals.

Elias related to the effect of relationships in professional commitment and intention to do whistleblowing, showed a significant relationship. If the frauds occur in the institution, employees with a strong professional commitment will be aware of the dangers of the fraud and immediately report it as a form of responsibility in working professionally for the smooth running of achieving organizational goals [11]. The higher the level of professional commitment, the higher the respondents tend to consider whistleblowing as something important and the higher their desire to become a whistleblower. Elias's research is supported by Mela et al [10] who found the same results.

- H4: Professional Commitment has a positive effect on Whistleblowing Intention.

\section{F. Anticipatory Socialization and Whistleblowing Intention}

Elias [11] states that not only professional commitment, anticipatory socialization also has a significant influence on 


\section{Ethics Scenario}

one's ethical orientation before entering into his organization. Elias [11] conducted a study to examine the effect of anticipatory socialization variables on whistleblowing, with the results showing that respondents with a high anticipatory socialization level were more motivated to reveal when a violation occurred through the whistleblowing mechanism.

Jalil [18] conducted a study on the effect of anticipatory socialization variables on whistleblowing intention, using a questionnaire reference developed by Clikeman to see perceptions of the importance of reporting, there are 4 factors to measure anticipatory socialization, 1) Misstate: to measure employee desires to report reports incorrectly, 2) Disclosures: to measure employee confidence that companies must disclose more information to report users. 3) Cost-benefit: indicates employee confidence that reporting has far more benefits than costs to be paid and 4) Responsibility: indicates employee confidence that managers are responsible for the accuracy of reporting.

- H5: Anticipatory Socialization has a positive effect on Whistleblowing Intention

\section{METHODS}

\section{A. Samples and Procedure}

In this research, the data were collected through a questionnaire from August to September 2019. Respondents were selected using non probability sampling method. Two Hundred and Sixty Eight government employee who served foreign tax payers, in South Jakarta, Indonesia responded to this survey. We analyse the data using PLS SEM 2.0 after data collection, which is a type of variance based SEM. It also allows the author to stimulate several models while still remaining based on theory.

\section{B. Research Model}

Based on the explanation mentioned above, the research model was constructed. This study uses a combination of two research models 1 ) the relationship between moral intensity, ethical decision making and whistleblowing intention [9] and 2) the relationship between professional commitment, anticipatory socialization and whistleblowing intention [10].

\section{Variables and Measurements}

A 6-point likert-type scale was used in order to measure respondent's level agreement with each item (1 = "Strongly Disagree"; $6=$ "Strongly Agree"). Moral Intensity was measured with 6 indicators formulated by [19], Ethical Decision Making was measured with 4 indicators formulated by Valentine and Godkin [9], Professional Commitment was measured with 5 indicators formulated by Dwyer in Mela et al [10], Anticipatory Socialization was measures with 11 indicators formulated by Clikemen in Mela et al [10] and Whistleblowing Intention was measures with 5 indicators formulated by Valentine and Godkin [9].
Moral intensity variable measurement is done by adopting an ethical scenario published in the journal [9], where the scenario is adopted from Dabholkar and Kellaris [5]. Other research that has successfully used this scenario to measure ethical decision-making processes that involve moral intensity that leads to intention to do whistleblowing, has been conducted by Stevenson and Bodkin [20]; Barnett and Valentine [21]. This scenario contains an ethical dilemma, because the policy of using airline A which provides a discounted price, is not explicitly written in the regulations, only in the form of encouragement and advice without inherent sanctions. This scenario highlights an employee's ethical selfish behaviour because he chose to use airline B at a far more expensive cost, in order to earn "frequent flier" points for his own benefit, even though the company still pays the employee's travel costs, the company has been financially disadvantaged .

This scenario was chosen with consideration:

- Presenting an ethical dilemma situation that often occurs in various government and private institutions and organizations, the case is easily recognized and understood and experienced by many employees with all different strata of positions and business professionals

- The situation in this scenario can result in the deposition of various ethical reactions.

- Including problems that can trigger other employees to do whistleblowing in response to perceived errors [9].

\section{E. Test Variables}

Before the main test was conducted, we carried out the pre-test stage to check the validity and reliability of all indicators. Validity test is useful to know that the research instrument measures the right thing while the reliability test needs to be done to determine the consistency of the research instrument if the measurement is repeated [22]. The minimum number of samples for statistical calculations in order to meet the normal frequency curve distribution is around 30 samples.

All measuring instruments of the research variables were tested for validity and reliability using SPSS 25. The research instrument is said, to be valid if the Kaiser Meyer-Olkin (KMO) value $>0.5$ or $\mathrm{r}$ count value $>\mathrm{r}$ table (significance value of 5\% is used) [23]. As for the reliability of research instruments, it can be seen from the Cronbach's alpha value that shows the average inter correlation of each research instrument. The value of Cronbach's alpha is considered satisfactory if it is more than 0.7 [22].

\section{F. Data Analysis Technique}

PLS-SEM version 2.0, a variance based SEM type, was used to analyse data in this research. This software allows writers to simulate several models and still based on theory. In addition, PLS SEM also provides some convenience with no requires various assumptions of Ordinary Least Squares (OLS) regression, such as normal data distribution, the absence of 
multi collinearity problems, the data does not have to meet various parametric assumptions, and construct indicators can be shaped reflexive and formative. SEM-PLS does not have to be supported by a strong theory and large sample size. There are five stages of the analysis process with using PLS SEM [24]:

- Conceptualization of the model,

- Algorithm analysis method,

- Resampling method,

- Drawing a path diagram, and

- Model evaluation.

\section{RESULTS AND DISCUSSION}

\section{A. Validity and Reliability.}

Before the main test was conducted, we carried out the pre-test stage to check the validity and reliability of all the indicators, to 30 respondents with the same characteristics as the respondents in main test. The result of pre-test showed that 8 of 31 indicators were invalid and unreliable, so they were not used in the main test.

In main test, validity and reliability testing of each construct was carried out once more to evaluate the measurement model for each latent variable. In total, there are 23 valid and reliable indicators, which are then used for main test analysis with 268 respondents with demographic as follows.

From the Demographics of Respondent, it can be concluded that the respondents' sex distribution of this research was dominated by male with percentage of $71 \%$, just the same as the characteristics of this government institution which is dominated by male employee. From age profile, the respondents ware dominated by 31-40 years old employee, which are considered as an $\mathrm{X}$ Generation. From Education indicators, a $55 \%$ of the respondents had bachelor degrees. Meanwhile, most of them were married $(83 \%)$.

The entire model evaluation can be seen from Average $\mathrm{R}$ square value of 0.455 (Refer to Cohen 1998, it considered as "Large") and Average communality value of 0.584 (Refer to Fornel and Lacker, it is fulfil the requirement), so based on Tenenhauset's formula [23]:

$$
\text { GoF }=\sqrt{ } \text { Communality } * \mathrm{R}
$$

Goodness of Fit (GoF) value for this research model is 0.516, which shows that the research model has $51.6 \%$ achievable fit, this model can be considered good.

\section{B. Test of Hypothesis.}

We assessed the hypothesis using SEM because it can test structural model and measurement models simultaneously [25]. A structural model analysis was carried out to test the significance of the hypothesis built with the structural evaluation results as shown in the figure as follows:

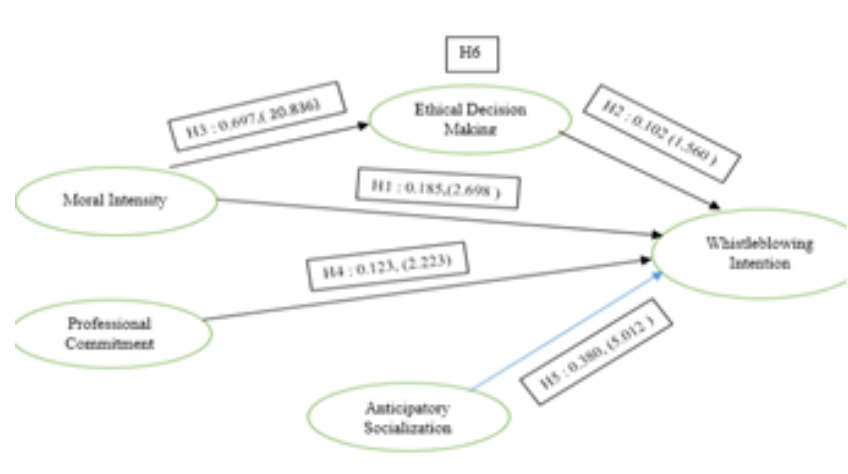

Fig. 1. SEM model research

TABle I. The Result Of Main Test - Direct Path CoefFicients

\begin{tabular}{|l|c|c|c|c|c|}
\hline $\begin{array}{c}\text { Hypo } \\
\text { thesis }\end{array}$ & Path & $\begin{array}{c}\text { Path } \\
\text { Coeffi } \\
\text { cient }\end{array}$ & $\begin{array}{c}\text { T } \\
\text { States } \\
\text { tics }\end{array}$ & Result & Note \\
\hline H1 & MI $\rightarrow$ WBI & 0.185 & 2.698 & $\begin{array}{l}\text { Positive \& } \\
\text { Significant }\end{array}$ & Accepted \\
\hline H2 & EDM $\rightarrow$ WBI & 0.102 & 1.560 & $\begin{array}{l}\text { Positive } \\
\text { but not } \\
\text { Significant }\end{array}$ & Rejected \\
\hline H3 & MI $\rightarrow$ EDM & 0.697 & 20.836 & $\begin{array}{l}\text { Positive \& } \\
\text { Significant }\end{array}$ & Accepted \\
\hline H4 & PC $\rightarrow$ WBI & 0.123 & 2.223 & $\begin{array}{l}\text { Positive \& } \\
\text { Significant }\end{array}$ & Accepted \\
\hline H5 & AS $\rightarrow$ WBI & 0.380 & 5.012 & $\begin{array}{l}\text { Positive \& } \\
\text { Significant }\end{array}$ & Accepted \\
\hline
\end{tabular}

TABLE II. THE EFFECT OF MEDIATION

\begin{tabular}{|l|l|l|l|l|}
\hline Structural Path & $\begin{array}{c}\text { Direct } \\
\text { Effect }\end{array}$ & $\begin{array}{c}\text { Indirect } \\
\text { Effect }\end{array}$ & $\begin{array}{c}\text { Total } \\
\text { Effect }\end{array}$ & $\begin{array}{c}\text { Conclusion } \\
\text { Mediation } \\
\text { Type }\end{array}$ \\
\hline $\mathrm{MI} \rightarrow \mathrm{EDM} \rightarrow \mathrm{WBI}$ & 0.185 & 0.071 & 0,256 & $\begin{array}{l}\text { Rejected } \\
\text { Direct Only } \\
\text { (No Mediation) }\end{array}$ \\
\hline
\end{tabular}

\section{Discussion}

First, we will analyse whether ethical decision making can be a mediator variable for the relationship of moral intensity and whistleblowing intention, as the results of Valentine and Godkin [9] study stated that there is a positive relationship for all direct relationships of each variable of moral intensity, ethical decision making and whistleblowing intention, in this case the relationship $\mathrm{H} 1, \mathrm{H} 2$ and $\mathrm{H} 3$. It turns out that the findings of this study differ from the results of the study Valentine and Godkin [9] which states that ethical decision making has a positive and significant effect on whistleblowing intention and Hypothesis $\mathrm{H} 6$ where ethical decision making has a positive and significant role as a mediator variable in the relationship of moral intensity and whistleblowing intention. This difference is due to differences in the organizational cultural background of the respondent's institution and the sensitivity level of moral sensitivity based on moral values adopted by these government institution employees as well as consideration in the employee when deciding that this unethical situation is not necessary until reported through 
whistleblowing. Respondents agreed that the use of official airplane tickets for personal gain is unethical action, especially in terms of the probability of effect and concentration of effects, and this encourages them not to do the same thing as those committed by employees (especially ethical intention), but this is not enough to encourage respondents to report through whistleblowing.

Second, related to the relationship between professional commitment and anticipatory socialization both have a positive and significant value on whistleblowing intention, this is somewhat different from the results of research Elias [11] which states that professional commitment has a positive and significant value on whistleblowing intention but is negatively related to anticipatory socialization and whistleblowing intention. But the results of this study support the research of Elias [11], that the higher the level of professionalism possessed by an employee, then if he feels that something unethical can hurt his profession and institution, the more he is compelled to report such unethical actions through whistleblowing. Likewise, the role of professional and institutional values that are strongly embedded, long before the respondent becomes an employee of the institution, can encourage reporting when he feels that unethical conduct is contrary to the values of his profession and institution. Therefore, this government institution needs to 1) multiply activities that can increase a sense of moral sensitivity, 2) make regulations and codes of ethics that emphasize unethical actions that have the potential to harm the organization to avoid ambiguity and 3) strengthen the planting of professional and organizational values in order to become a stronghold that can protect the organization from fraud perpetrated by its employees and encourage other employees to report when fraud occurs through a whistleblowing mechanism with some improvements tailored to the characteristics of its employees. An act that is unethical if done continuously can become a habit especially if it is considered normal for most people, it can potentially lead to fraud that harms the organization and the state and the trust of the community.

\section{CONCLUSION}

Based on research on the influence of moral intensity, ethical decision making, professional commitment and anticipatory socialization towards whistleblowing intention on employees working in Government Institutions in the field of taxation, it was concluded that the level of moral intensity contained in an employee of a Government Institution has a positive effect on ethical decision making and encouragement of the intention to do whistleblowing, especially from the probability of effect and concentration of effect factors on the perception of an unethical act. However, the ethical decision making process of the ethical scenarios presented, apparently did not affect the employee's intention to become a whistleblower because of differences in the character and culture of the organization, in this case Government Institutions.

As for the professional commitment and anticipatory socialization factors, both of them have a positive effect on employee intention to do whistleblowing, this finding strengthens the results of research conducted by Elias [11], but contrary to the research results of Mela and Zarefar [10] which states that anticipatory socialization is not related to whistleblowing intention.

The topic related to the whistleblowing system is very important and interesting to be examined more deeply, with the object of research that plays a crucial role and a world window because it deals directly with Foreign Taxpayers, in an effort to prevent the practice of violating the code of ethics and/or discipline and fraud in this Government Institution. By knowing how much the factor of moral intensity, ethical decision making, professional commitment, and anticipatory socialization can influence employee intentions to take action whistleblowing, the authors hope to provide input to government in designing effective whistleblowing policies and systems.

\section{REFERENCES}

[1] B. Sweeney and F. Costello,"Moral Intensity and Ethical DecisionMaking: An Empirical Examination of Undergraduate Accounting and Business Students," Accounting Education, vol.18, no. 1, pp. 75-97, 2009.

[2] R.K. Chiu, "Ethical Judgment and Whistleblowing Intention: Examining the Moderating Role of Locus of Control," Journal of Business Ethics, vol. 43, pp. 65-74, 2003.

[3] L.L. Watts and M.R. Buckley, "A dual-processing model of moral whistleblowing in Organizations," Journal of Business Ethics, vol. 146, pp. 669-683, 2017.

[4] T. Jones, "Ethical Decision Making by Individuals in Organizations: An Issue-Contingent Model," Academy of Management Review, vol. 16, no. 2, pp. 366-395, 1991.

[5] P.A. Dabholkar and J.J. Kellaris, “Toward Understanding Marketing Students' Ethical Judgment of Controversial Selling Practices," Journal of Business Research, vol. 24, no. 4, pp. 313-329, 1992.

[6] T. Barnett, D.S. Cochran, and G.S. Taylor, "The Internal Disclosure Policies of Private-Sector Employers: An Initial Look at Their Relationship to Employee Whistleblowing," Journal of Business Ethics, vol. 12, pp. 127-136, 1993.

[7] Rest, Moral Development: Advances in Research and Theory, New York: Praeger, 1986.

[8] D.P. Robin, R.E. Reidenbach, and P. Forrest, "The Perceived Importance of An Ethical Issue as An Influence on the Ethical DecisionMaking of Ad Managers," Journal of Business Research, vol. 35, pp. 17-28, 1996.

[9] S. Valentine and L. Godkin, "Moral Intensity, Ethical Decision Making, and Whistleblowing Intention," Journal of Business Research, vol. 98, pp. 277-288, 2019.

[10] N.F. Mela, N.A. Zarefar, and Andreas, "The Relationship of Professional Commitment of Auditing Student and Anticipatory Socialization toward Whistleblowing Intention," Procedia - Social and Behavioral Sciences, vol. 219, pp. 507-512, 2016.

[11] Elias, "Auditing Students' Professional Commitment and Anticipatory Socialization and Their Relationship to Whistleblowing," Managerial Auditing Journal, vol. 23, pp. 283-294, 2008.

[12] P. Hardiningsih. "Faktor-faktor yang Mempengaruhi Kemauan Membayar Pajak," Dinamika Keuangan dan Perbankan, 2011.

[13] B. Bjorkelo, S. Einarsen, and S. B. Matthiesen, "Predicting Proactive Behaviour at Work: Exploring the Role of Personality as An Antecedent of Whistleblowing Behaviour," Journal of Occupational and Organizational Psychology, vol. 83, no. 2, pp. 371-394, 2010.

[14] M.P. Miceli and J.P. Near, "Individual and Situational Correlates of Whistleblowing," Personnel Psychology, vol. 41, pp.267-281, 1988.

[15] A.A. Putra and E. Hariyani, "Pengaruh Komitmen Profesional, Lingkungan Etika, Intensitas Moral, Personal Cost Terhadap Intensi Untuk Melakukan Whistleblowing Internal Studi Empiris Pada Opd Kabupaten Bengkalis," Jurnal Akuntansi Keuangan dan Bisnis, vol 11 no. 2 , pp. $17-26,2018$. 
[21] T. Barnett and S. Valentine, "Issue Contingencies and Marketers' Recognition of Ethical Issues, Ethical Judgments and Behavioral Intentions," Journal of Business Research, vol. 57, pp. 338-346, 2004.

[16] I. Setyawati, "Faktor-Faktor yang Mempengaruhi Niat untuk Melakukan Whistleblowing Internal,” Jurnal Ekonomi dan Bisnis, vol. 17, 2015.

[17] L.K. Trevino, L.P. Hartman, and M. Brown, "Moral Person and Moral Manager: How Executives Develop a Reputation for Ethical Leadership," California Management Review, vol. 42, no. 4, 2000.

[18] F.Y. Jalil, "Pengaruh Komitmen Profesional dan Sosialisasi Antisipatif Mahasiswa Audit terhadap Perilaku Whistleblowing," Jurnal Bisnis dan Manajemen, vol. 4, No. 2, 2004.

[19] D.R. May and K.P. Pauli, "The Role of Moral Intensity in Ethical Decision Making," Business \& Society, vol. 41, no. 1, pp. 84-117, 2002.

[20] T.H. Stevenson and C.D. Bodkin, "A Cross-National Comparison of University Students' Perceptions Regarding the Ethics and Acceptability of Sales Practices,” Journal of Business Ethics, vol. 17, pp.45-55, 1998.
[22] U. Sekaran and R. Bougie, Research Methods for Business, a Skill Building Approach, 5th ed., United Kingdom: John Wiley and Sons Ltd, 2009.

[23] J.F. Hair, W.C. Black, B.J. Babin, and R. E. Anderson, Multivariate Data Analysis, 7th ed., Harlow: Pearson Education Limited, 2014.

[24] H. Latan and I. Ghozali, "Partial Least Squares: Konsep, Teknik dan Aplikasi Menggunakan Program SmartPLS 2.0 M3, Semarang: Badan Penerbit Universitas Diponegoro, 2012.

[25] S.H. Wijanto, Metode Penelitian Menggunakan Sructural Equation Modelling dengan Lisrel 8.8:Konsep dan Tutorial, Yogyakarta: Graha Ilmu, 2008. 